\title{
PERBANDINGAN KINERJA KARYAWAN SEBELUM DAN SESUDAH PEMBERIAN PENDIDIKAN DAN PELATIHAN PADA PT. ASURANSI INTRA ASIA CABANG MEDAN
}

\author{
Ida M. Manulang \\ Universitas Katolik Santo Thomas Medan Jl. Setia Budi No. 479F, 20132, Indonesia \\ e-mail: idamanullangunika@yahoo.com
}

\begin{abstract}
This study aims to analyze the comparison of employee performance before and after the provision of education and job training at PT. Intra Asia Insurance Medan Branch. Data collection by interviews and documentation. The population is all employees of the company and the sample in this study uses saturated samples, namely sampling to all agents totaling 35 people. Data analysis techniques with different test two average paired samples. The results of the study resulted in a level of difference before and after the provision of education and job training showed a z_count value of 24.23> 1.96 which means that there were significant differences between the performance of employees after and received training before getting training. From the results of hypothesis testing, the formulation of the hypothesis proposed for validity test shows that there are significant differences in employee performance before and after the provision of education and job training. Thus, the hypothesis proposed in this study can be accepted.Suggestions given, the company should provide education and training regularly, especially for employees with performance that does not meet the standards and providing education and training for employees who have met the standards also need to be done in an effort to increase the policy targets set by the company.
\end{abstract}

\section{Keywords: Education, Training and Performance}

\section{PENDAHULUAN}

Dalam menghadapi era globalisasi, banyak tantangan yang harus dihadapi oleh perusahaan dalam rangka memenangkan persaingan. Salah satu faktor yang dapat dijadikan pegangan perusahaan dalam menciptakan keunggulan bersaing adalah dengan keunggulan produk dan sumber daya manusia yang berkualitas yang akan memberikan kontribusi bagi penciptaan keunggulan bersaing pada era globalisasi.

Untuk mempersiapkan sumber daya manusia tidak hanya dilihat dari segi kuantitasnya saja, sebab tersedianya sumber daya manusia yang cukup banyak belum tentu merupakan jaminan bahwa hasil yang dicapai akan efisien dan efektif. Sebagai langkah awal untuk mendapatkan sumber daya manusia yang berkualitas adalah dimulai dengan menarik dan memilih tenaga kerja yang sesuai dengan standar personalia perusahaan. Langkah selanjutnya untuk terus meningkatkan sumber daya manusia yang terampil dan berkemampuan tinggi adalah dengan memberikan pendidikan dan pelatihan terhadap setiap pelaku organisasi secara berkesinambungan dengan metode yang sistematis.

Menurut Notoadmodjo (2009:16), pendidikan dan pelatihan merupakan upaya untuk mengembangkan SDM terutama untuk mengembangkan kemampuan intelektual dan kepribadian manusia. Sedangkan menurut Jan Bella (dalam Hasibuan, 2006:70) bahwa pendidikan dan pelatihan sama dengan pengembangan yaitu merupakan proses peningkatan keterampilan kerja baik teknis maupun manajerial. Pendidikan berorientasi pada teori, dilakukan didalam kelas, berlangsung lama, dan biasanya menjawab why. Pelatihan berorientasi pada praktek, dilakukan di lapangan, berlangsung singkat dan biasanya menjawab how.

Meskipun pelatihan tenaga kerja memerlukan biaya yang tidak sedikit tetapi pelatihan harus tetap dilaksanakan karena pelatihan tersebut mempunyai manfaat yang besar bagi perusahaan. Manfaaat bagi perusahaan antara lain adalah perusahaan mempunyai tenaga 
kerja yang siap melaksanakan pekerjaannya sehingga perusahaan dapat mencapai tujuannya dengan lebih mudah. Dengan dilaksanakan program pendidikan dan pelatihan diharapkan pegawai akan semakin mampu memahami dan melaksanakan fungsinya dalam organisasi. Disamping itu, diharapkan adanya perbaikan ataupun pengembangan sikap, tingkah laku, pengetahuan serta keterampilan dari para pelaku organisasi agar tercapainya tujuan perusahaan.

Pendidikan dan pelatihan yang dilakukan perusahaan terhadap karyawan akan berdampak positif pada pencapaian kinerja karyawan. Menurut Mangkunegara (2010:16) kinerja (prestasi kerja) adalah hasil kerja secara kualitas dan kuantitas yang dicapai oleh seseorang pekerja dalam melaksanakan tugasnya sesuai dengan tanggung jawab yang diberikan kepadanya. Kinerja adalah hasil atau tingkat keberhasilan seseorang secara keseluruhan selama periode waktu tertentu di dalam melaksankan tugas dibandingkan dengan berbagai kemungkinan, seperti standar hasil kerja, target atau sasaran atau kriteria yang telah di tentukan terlebih dahulu dan telah di sepakati bersama (Rivai dan Basri, 2005:15).

Menurut Rivai dan Basri (2005:50) "Kinerja adalah hasil atau tingkat keberhasilan seseorang secara keseluruhan selama periode tertentu dalam melaksanakan tugas dibandingkan dengan berbagai kemungkinan, seperti standar hasil kerja, target atau sasaran atau kriteria yang telah ditentukan terlebih dahulu dan telah disepakati bersama" sedangkan menurut Sedarmayanti (2011:260) mengungkapkan bahwa "Kinerja merupakan terjemahan dari performance yang berarti hasil kerja seorang pekerja, sebuah proses manajemen atau suatu organisasi secara keseluruhan, dimana hasil kerja tersebut harus dapat ditunjukkan buktinya secara konkrit dan dapat diukur (dibandingkan dengan standar yang telah ditentukan)".

Berikut adalah Hasil penelitian terdahulu oleh Cut Asmara Nur (2005), mengenai Analisis Perbedaan Kinerja Karyawan PT. Ata Sadira Surabaya Sebelum dan Sesudah Outbound Training, menyimpulkan bahwa dari hasil pengujian dengan menggunakan uji beda diketahui bahwa terdapat perbedaan yang signifikan pada kinerja karyawan sebelum dan sesudah mengikuti outbound training.

Hasil penelitian Fiolita (2017), dengan judul : analisis perbedaan sebelum dan sesudah pelatihan modul 2000 karyawan PT. Fastfood Indonesia Tbk. ( KFC Adityawarman Surabaya). Hasil penelitian menunjukkan terdapat perbedaan yang kuat dan signifikan antara sebelum dan sesudah pelatihan modul 2000 terhadap kinerja karyawan di PT. Fastfood Indonesia, Tbk.

Hasil penelitian, Putri (2012) dengan judul : Analisis Kinerja Keuangan Perusahaan Sebelum dan Sesudah Diadakannya Training ESQ (Emotional Spiritual Quotient), (Studi Pada Perusahaan Yang Mengadakan Training ESQ Periode 2007 - 2009). Berdasarkan Uji t -test yaitu Paired Sample Test. Ada perbedaan kinerja keuangan perusahaan sebelum dan sesudah diadakannya Training ESQ yaitu pada PT. Bukit Asam Rasio Perputaran Persediaan. Perusahaan Gas Negara adalah Rasio Lancar, Rasio Cepat, Return On Invesment. Telekomunikasi Indonesia adalah Rasio Cepat, Return On Asset, Rasio Perputaran Persediaan. Indosat adalah Rasio Kelipatan Pembayaran Hutang (TIE). Hal ini berarti, terdapat perbedaan kinerja keuangan sebelum dan sesudah diadakannya Training ESQ, namun peningkatan tersebut tidak signifikan. Hal ini dikarenakan tidak semua karyawan perusahaan mengikuti Training ESQ dan juga rentan waktu dalam pengadaan Training ESQ. Serta kurangnya minat dan kemauan dari para karyawan untuk mengikuti Training ESQ. Karena pelatihan pada karyawan tidak akan berjalan dan menghasilkan suatu hasil yang memuaskan tanpa ada kemauan dari diri mereka sendiri. Kemauan yang dimaksud adalah proses perubahan diri dari kinerja negatif ke positif, dan dari hasil yang tidak memuaskan menjadi lebih memuaskan.

PT. Asuransi Intra Asia Cabang Medan adalah sebuah perusahaan yang bergerak dibidang pelayanan asuransi kerugian. Komitmen perusahaan untuk mengutamakan 
kepuasan nasabah dengan memberikan kemudahan, kecepatan pelayanan dan didukung oleh produk yang inovatif serta tenaga-tenaga profesional telah menjadikan para nasabah tetap setia menggunakan jasa asuransi PT. Asuransi Intra Asia Cabang Medan. Perusahaan menawarkan berbagai solusi asuransi yang komprehensif meliputi cakupan layanan bagi nasabah yang lebih luas, mulai dari individu, perusahaan hingga pasar komersial, serta membangun dan membina hubungan jangka panjang dan kemitraan yang erat disegala situasi. Kini perusahaan telah memiliki berbagai produk asuransi dengan 20 kantor cabang dan pemasaran diseluruh indonesia.

Berdasarkan hasil penelitian pada PT. Asuransi Intra Asia Cabang Medan bahwa pendidikan dan pelatihan kerja merupakan upaya untuk mengurangi atau menghilangkan kesenjangan antara kemampuan karyawan dengan harapan organisasi. Meskipun upaya organisasi untuk menjembatani kesenjangan tersebut melalui pendidikan dan pelatihan, tidak serta merta meningkatkan kinerja karyawan karena permasalahan yang terjadi dilapangan bahwa pelaksanaan diklat tidak dapat terserap secara maksimal oleh para peserta diklat. Misalnya persiapan pelaksanaan metode dan materi pendidikan dan pelatihan yang diajarkan akan berpengaruh terhadap minat belajar peserta diklat, karena setiap orang memiliki kemampuan untuk menyerap materi dan metode belajar yang berbeda-beda sehingga dapat menimbulkan ketertarikan terhadap program diklat tersebut. PT. Asuransi Intra Asia Cabang Medan sudah membut program-program pendidikan dan pelatihan yang dilaksanakan oleh karyawan dengan aturan- aturan yang telah ditentukan. Namun kinerja setiap agen asuransi tidak semua meningkat pasca mengikuti diklat. Hal ini disebabkan dua faktor dalam sulitnya mencari nasabah yaitu: Faktor skill yang dimana memiliki hubungan bagaimana cara seorang agen asuransi mendapatkan nasabah sesuai dengan kemampuan mereka untuk mempersuasi nasabah dengan menggunakan proses komunikasi yang baik dan tepat dan Faktor Knowledge yang dimana memiliki hubungan dengan pengetahuan agen asuransi terhadap produkproduk yang akan dipasarkannya.

Sehubungan dengan latar belakang masalah yang diuraikan diatas, penulis tertarik untuk mengadakan penelitian dengan judul : "Analisis Perbandingan Kinerja Karyawan Sebelum dan sesudah Pemberian Pendidikan dan Pelatihan Pada PT. Asuransi Intra Asia Cabang Medan.

Dari uraian latar belakang penelitian, peneliti merumuskan masalah sebagai berikut: Apakah terdapat perbedaan sebelum dan sesudah pemberian pendidikan dan pelatihan kerja terhadap kinerja karyawan pada PT. Asuransi Intra Asia Cabang Medan?

\section{TINJAUAN PUSTAKA}

\section{A. Pengertian Manajemen Sumber Daya Manusia}

Perusahaan sebagai salah satu bentuk organisasi membutuhkan sumber daya manusia dalam merealisasikan tujuannya, karena manusia merupakan faktor yang terpenting yang selalu berperan aktif dan dominan dalam setiap kegiatan maupun perilaku organisasi. Manajemen sumber daya manusia adalah suatu bidang manajemen yang khusus mempelajari hubungan dan peranan manusia dalam organisasi perusahaan. Unsur manajemen sumber daya manusia adalah manusia yang merupakan tenaga kerja pada perusahaan. Dengan demikian fokus yang dipelajari Manajemen Sumber Daya Manusia ini hanyalah masalah yang berhubungan dengan tenaga kerja manusia saja.

Agar pengertiannya lebih jelas, maka di bawah ini terdapat beberapa definisi yang telah dirumuskan dan dikemukakan oleh para ahli: Menurut Hasibuan ( 2002: 10 ) yaitu: "Manajemen sumber daya manusia adalah ilmu dan seni mengatur hubungan dan peranan tenaga kerja agar fektif dan efisien membantu terwujudnya tujuan perusahaan, karyawan, dan masyarakat". Menurut Handoko (2000 : 4) yaitu: "Manajemen Sumber Daya Manusia adalah proses penarikan, seleksi, pengembangan, pemeliharaan, dan penggunaan sumber daya manusia untuk mencapai baik tujuan-tujuan individu maupun organisasi.". 
Dari penjelasan di atas serta pendapat-pendapat para ahli tentang definisi manajemen sumber daya manusia, penulis berusaha mencoba mengartikan definisi Manajemen Sumber daya Manusia sebagai suatu perencanaan, pengorganisasian, pengarahan, dan pengawasan atas pengadaan, pengembangan, kompensasi, pengintegrasian, pemeliharaan, dan pemutusan hubungan kerja dengan maksud untuk mencapai tujuan organisasi perusahaan secara terpadu.

\section{B. Fungsi Manajemen Sumber Daya Manusia}

Hasibuan (2002 : 21), mengklasifikasikan ruang lingkup Manajemen Sumber Daya manusia menjadi 2 fungsi pokok yaitu :

1. Fungsi Manajerial

a. Perencanaan ( Planning ). Perencanaan adalah merencanakan tenaga kerja secara efektif dan efisien agar sesuai dengan kebutuhan perusahaan dalam membantu terwujudnya tujuan. Bagi manajer personalia, perencanaan berarti penentuan program personalia, yang akan membantu tercapainya sasaran yang telah disusun untuk perusahaan yang bersangkutan. Dengan perkataan lain, proses penentuan sasaran akan melibatkan partisipasi aktif manajer personalia. Perencanaan merupakan dasar dari fungsi-fungsi manajemen lainnya, sekaligus merupakan perumusan persoalan-persoalan mengenai apa dan bagaimana suatu pekerjaan hendak dilaksanakan, melalui penetapan sasaran yang harus dicapai. Dengan demikian, perencanaan dianggap sebagai kumpulan keputusan yang dasar bagi tindakan-tindakan di masa yang akan datang.

b. Pengorganisasian (Organizing). Pengorganisasian adalah kegiatan untuk mengorga nisasi semua karyawan dengan menetapkan pembagian kerja, hubungan kerja, delegasi wewenang, integrasi, dan koordinasi dalam bagan organisasi. Organisasi adalah personalia tertentu akan membantu ke arah tercapainya sasaran perusahaan, maka manajer personalia harus menyusun suatu organisasi, dengan merencanakan struktur hubungan antara pekerja, personalia, dan lain-lain. Pengorganisasian merupakan tugas manajer untuk menyusun pembagian kerja dan menentukan tanggung jawab, serta menjaga hubungan antar kelompok sedemikian rupa sehingga mereka dapat melaksanakan berbagai aktivitas untuk mencapai sasaran yang telah ditetapkan. Salah satu tugas pokok organisasi, adalah mengalokasikan bermacam-macam kepentingan untuk kemudian memanfaatkan seluruh kemampuan yang ada ke arah tercapainya suatu tujuan.

c. Pengarahan (Directing). Pengarahan adalah kegiatan mengarahkan semua karyawan, agar mau bekerja sama dan bekerja efektif serta efisien dalam membantu tercapainya tujuan perusahaan. Pengarahan berhubungan dengan usaha memberikan bimbingan, saran-saran, perintah-perintah atau instruksi-instruksi kepada bawahan, dalam pelaksanaan tuganya masing-masing. Pengarahan berfungsi mengkoordinasi berbagai kegiatan organisasi agar berjalan efektif dan tertuju pada realisasi yang telah ditetapkan, serta mampu menggerakkan orang lain untuk menyeselesaikan pekerjaan, memotivasi, dan membina moral pegawai.

d. Pengendalian (Controlling). Pengendalian adalah kegiatan mengendalikan semua karyawan, agar mentaati peraturan-peraturan perusahaan dan bekerja sesuai dengan rencana. Fungsi pengendalian dilakukan sebagai pengamatan atas tindakan dan perbandingannya, dengan rencana perbaikan atas terhadap penyimpangan yang mungkin terjadi, atau penyesuaian terhadap penyimpangan yang tidak dapat diubah serta berfungsi mengkoreksi pelaksanaan pekerjaan.

2. Fungsi Operasional

a. Pengadaan Tenaga Kerja (Procurement). Pengadaan Tenaga Kerja adalah kegiatan untuk memperoleh kuantitas dan kualitas tenaga kerja yang diperlukan. Hal ini meliputi penarikan tenaga kerja, seleksi, serta penempatannya. 
b. Pengembangan (Development). Pengembangan adalah proses yang bertujuan untuk meningkatkan keterampilan, pengetahuan, serta kemampuan karyawan yang diperlukan untuk melaksanakan pekerjaan tertentu sehingga ia dapat bekerja dengan lebih baik di perusahaan tersebut.

c. Kompensasi (Compensation). Kompensasi yaitu pemberian imbalan atau penghargaan kepada karyawan atas dasar prestasi yang mereka capai di perusahaan tersebut.

d. Pengintegrasian (Integration). Pengintegrasian adalah kegiatan untuk mempersatukan kepentingan perusahaan dan kebutuhan karyawan, agar tercipta kerja sama yang selaras dan saling menguntungkan.

e. Pemeliharaan (Maintenance). Pemeliharaan adalah kegiatan untuk memelihara atau meningkatkan kondisi fisik, mental, dan loyalitas karyawan, agar mereka tetap mau bekerja dalam perusahaan selamanya.

f. Kedisiplinan. Kedisiplinan yaitu keinginan dan kesadaran untuk mentaati peraturanperaturan perusahaan dan norma-norma sosial.

g. Pemutusan Hubungan Kerja (PHK). Pemutusan hubungan kerja adalah memutuskan hubungan kerja dan mengembalikan orang-orang tersebut kepada masyarakat. Perusahaan bertanggung jawab untuk melaksanakan proses pemisahan sesuai dengan persyaratan-persyaratan yang telah ditentukan dan menjamin bahwa orang tersebut berada dalam keadaan baik.

\section{Tujuan Manajemen Sumber Daya Manusia}

Pada dasarnya ada beberapa tujuan manajemen sumber daya manusia menurut Sofyandi (2008:11) dapat dikategorikan pada empat jenis yaitu:

1. Tujuan Organisasional. Ditujukan untuk dapat mengenali keberadaan manajemen sumber daya manusia dalam pencapaian efektivitas organisasi.

2. Tujuan Fungsional. Ditujukan untuk mempertahankan kontribusi departemen pada tingkat yang sesuai dengan kebutuhan organisasi.

3. Tujuan Sosial. Ditujukan secara etis dan sosial merespon terhadap kebutuhan-kebutuhan dan tantangan-tantangan masyarakat melalui tindakan meminimalisir dampak negatif terhadap organisasi.

4. Tujuan Personal. Ditujukan untuk membantu karyawan dalam pencapaian tujuannya, minimal tujuan-tujuan yang dapat mempertinggi kontribusi individual terhadap organisasi.

Jadi dapat disimpulkan peranan manajemen sumber daya manusia menjadi sangat penting. Sasarannya tidak lagi terbatas pada menjamin kepatuhan para anggota organisasi kepada ketentuan-ketentuan di bidang kepegawaian, melainkan diarahkan kepada maksimalisasi kontribusi yang mungkin diberikan oleh setiap orang ke arah tercapainya tujuan organisasi yang telah ditentukan sebelumnya.

\section{Pendidikan dan Pelatihan}

Untuk memenuhi kebutuhan akan tenaga kerja yang bermutu dan mampu melaksanakan tugasnya dengan baik, maka salah satu usaha yang dapat dilakukan oleh perusahaan adalah dengan program pendidikan dan pelatihan. Pendidikan dan pelatihan perlu dilaksanakan oleh setiap perusahaan secara berkesinambungan, agar tenaga kerja yang dimiliki benar-benar bermutu, tepat dan mempunyai keahlian serta keterampilan yang sesuai dengan yang dituntut oleh pekerjaannya. Disamping itu perkembangan lingkungan eksternal maupun internal yang selalu berubah, yang mengakibatkan kesenjangan antara tuntutan perusahaan atau pekerjaan dengan kemampuan tenaga kerja, juga merupakan salah satu penyebab kebutuhan akan pendidikan dan pelatihan yang berkesinambungan.

Menurut Ambar (2009: 219), mengartikan bahwa pendidikan dan pelatihan adalah suatu usaha untuk memelihara, meningkatkan kemampuan, kapasitas maupun profesi onalisme 
karyawan. Sedangkan menurut Yusuf (2015:69), mendefinisikan pelatihan merupakan bagian dari pendidikan. Pelatihan bersifat spesifik, praktis dan segera. Spesifik berarti pelatihan berhubungan dengan bidang pekerjaan yang dilakukan. Praktis dan segera berarti yang sudah dilatihkan dapat dipraktikan. Umumnya pelatihan dimaksudkan untuk memperbaiki penguasaan berbagai keterampilan kerja dalam waktu relatif singkat. Hal tersebut penting karena cara yang digunakan oleh organisasi untuk mempertahankan, menjaga, memelihara karyawan publik dalam organisasi dan sekaligus meningkatkan keahlian para karyawan untuk kemudian dapat meningkatkan kinerjanya.

\section{E. Tujuan Pendidikan dan Pelatihan}

Pada dasarnya tujuan pendidikan dan pelatihan adalah suatu deskripsi dari pengetahuan sikap, tindakan, penampilan, dan sebagainya yang diharapkan akan dimiliki oleh sasaran pendidikan pada periode tertentu. Lahirnya tujuan pendidikan dan pelatihan disebabkan karena diperlukannya suatu kurikulum yang efektif dan efisien. Maksud menetapkan tujuan pendidikan terlebih dahulu, agar memudahkan dan mengarahkan penyusunan kurikulum. Berikut tujuan dari pendidikan dan pelatihan yang dikemukakan oleh Sikula (2003:69)

1. Peningkatan Produktivitas (Increased productivity. Program pendidikan dan pelatihan dapat meningkatkan job performance pada posisi jabatannya sekarang. Jika level of performance meningkat maka berarti peningkatan produktivitas kerja dan pada akhirnya meningkatkan keuntungan bagi perusahaan.

2. Peningkatan Kualitas (Improved Quality). Pendidikan dan pelatihan akan mempunyai pengetahuan yang lebih baik dan Dengan adanya pendidikan dan pelatihan diharapkan adanya kualitas maupun kuantitas dalam bentuk produk atau jasa yang dihasilkan. Karyawan yang telah mengikuti program pendidikan memperkecil kesalahan dalam kegiatan operasionalnya.

3. Perencanaan Sumber Daya Manusia Yang Lebih Baik (Better Human Resources Planning). Program pendidikan dan pelatihan yang baik dapat mempersiapkan tenaga kerja untuk keperluan di masa datang. Pendidikan dan pelatihan karyawan dapat membantu perusahaan untuk mengisi atau memenuhi kebutuhan dan persyaratan personil masa depan.

4. Meningkatnya Semangat Kerja (Increased Morale).Jika perusahaan mengadakan pendidikan dan pelatihan yang tepat maka iklim pada umumnya akan menjadi lebih baik. Dengan iklim kerja yang sehat maka semangat kerja karyawan akan meningkat.

5. Kompensasi Tidak Langsung (Indirect Compensation). Banyak pekerja, khususnya manajer mempertimbangkan kesempatan pendidikan dan gaji bagian dari keseluruhan pemberian upah bagi para pegawai. Mereka mengharapkan perusahaan membayar sejumlah uang untuk program pendidikan dan pelatihan yang mengarah pada peningkatan pengetahuan umum dan keterampilan. Jadi banyak organisasi menawarkan program pendidikan dan pelatihan sebagai teknik Recruitment untuk menarik tenaga kerja potensial dengan kualitas tinggi.

6. Kesehatan dan Keselamatan Yang Lebih Baik (Better Health and Safety). Melalui pendidikan dan pelatihan yang tepat karyawan akan lebih menguasai pekerjaan dan dapat membantu menghindari terjadinya kecelakaan-kecelakaan dalam bekerja. Selain itu lingkungan kerja menjadi lebih aman dan akan mempengaruhi sikap mental yang lebih stabil dari para karyawan.

7. Pencegahan Kadaluarsa (Obsolescence Prevention). Program pendidikan dan pelatihan membantu meningkatkan inisiatif dan kreativitas para karyawan serta membantu mengadakan tindakan preventif untuk menghadapi ketinggalan zaman akibat dari kemajuan teknologi. 
8. Pengembangan Diri (Personal Growth). Seorang karyawan yang telah mendapatkan pendidikan dan pelatihan akan lebih matang bagi karyawan yang bersangkutan, pada akhirnya juga akan memberikan keuntungan kepada perusahaan.

\section{F. Prinsip-prinsip Pendidikan dan Pelatihan}

Pendidikan dan pelatihan dapat dipandang sebagai salah satu bentuk investasi, oleh karena itu bagi setiap organisasi yang ingin berkembang, maka pendidikan dan pelatihan bagi karyawannya harus memperoleh perhatian yang besar. Beberapa hal yang sangat penting untuk diperhatikan di dalam menyelenggarakan program pendidikan dan pelatihan adalah :

1. Perbedaan Individu. Di dalam merencanakan suatu program pendidikan dan pelatihan, seorang instruktur harus menyadari akan adanya individu dari masing-masing peserta. Daya tangkap dari setiap peserta berbeda-beda dan selain itu masih ada perbedaan lainnya seperti perbedaan latar belakang, pendidikan, pengalaman, dan minat.

2. Motivasi. Motivasi merupakan faktor penting dalam membangkitkan semangat belajar. Setiap individu yang mempunyai tujuan tertentu dihubungkan dengan keperluan sehingga individu tersebut akan lebih tepat menyesuaikan diri dalam proses belajar.

3. Hubungan dengan Analisa Jabatan. Keterangan dari analisa jabatan harus menunjukan pengetahuan dan kecakapan apa yang diperlukan pengetahuan dan kecakapan apa yang diperlukan oleh masing-masing jabatan tersebut, kemudian program pendidikan dam pelatihan harus disesuaikan dengan kebutuhan tersebut.

4. Pemilihan Peserta dan Pelatih Pendidikan dan Pelatihan. Selain ditujukan untuk karyawan baru, program pendidikan dan pelatihan juga diperuntukkan untuk mempersiapkan karyawan lama yang mempunyai minat dan bakat untuk memenuhi keperluan jabatanjabatan penting di perusahaan. Oleh karena itu, untuk memenuhi keperluan tersebut maka perlu dipilih yang benar-benar tepat dapat mengajar dengan baik.

5. Prinsip-prinsip Belajar. Di dalam proses pendidikan dan pelatihan ada beberapa prinsip yang perlu diperhatikan yaitu:

a. Participation. Mengarahkan peserta agar ikut aktif di dalam program pendidikan dan pelatihan, dengan berpartisipasi maka peserta akan lebih cepat mengetahui dan menguasai apa yang telah diberikan.

b. Repetition. Pengulangan-pengulangan materi dalam pelaksanaan pendidikan akan lebih cepat untuk mengingat dan memahami apa yang telah diajarkan.

c. Relevance. Pelatih sebaiknya menerangkan secara menyeluruh mengenai suatu pekerjaan sebelum menerangkan secara khusus mengenai tugas-tugas. Hal ini dimaksudkan agar para peserta dapat melihat dengan jelas hubungan dari setiap tugas beserta prosedur yang benar.

d. Transference. Materi yang diberikan dalam program pendidikan dan pelatihan harus sesuai dengan kebutuhan dan tuntutan yang nantinya akan dihadapi dalam pekerjaan yang sebenarnya.

e. Feed Back. Setelah diselesaikannya suatu paket program pendidikan dan pelatihan, sebaiknya peserta diberi informasi mengenai kemajuan yang telah dicapai. Dengan demikian diharapkan dapat meningkatkan semangat dan motivasi belajar.

\section{G. Metode Pelaksanaan Program Pendidikan dan Pelatihan}

Pemilihan penggunaan metode atau teknik-teknik pendidikan dan pelatihan yang digunakan perusahaan bergantung pada beberapa pertimbangan. Ada beberapa metode pendidikan dan pelatihan yang dikemukakan menurut Sikula (2002:52). Pada umumnya metode pendidikan dan pelatihan dapat digolongkan menjadi dua bagian, yaitu :

1. Metode untuk pembinaan managerial skill:

a. Case study. Pada metode ini para peserta diberi suatu kasus dan permasalahanpermasalahan yang merupakan gambaran dari situasi yang mungkin dihadapi oleh 
perusahaan, kemudian para peserta menganalisis dan mencari pemecahan. Metode ini dimaksud untuk mengembangkan cara berfikir yang sistematis didalam memecahkan suatu masalah.

b. Seminar. Merupakan suatu pertemuan formal, dimana didalamnya terdapat diskusi tentang suatu masalah. Dalam pertemuan tersebut para peserta didorong untuk berperan secara aktif dengan mengemukakan ide-idenya, kemudian secara bersamasama dibahas, dievaluasi dan disempurnakan oleh peserta lainnya.

c. Role playing. Dalam role playing, peserta diminta untuk memerankan individu yang harus melaksanakan tugas atau pekerjaan tertentu. Metode ini dimaksudkan agar peserta mampu memperbaiki perilakunya untuk mengembangkan hubungan antar manusia dengan organisasi.

d. Sensitivity Training. Metode ini dimaksudkan untuk membina kesadaran dan kepekaan atas pola tingkah laku diri sendiri dan orang lain. Tujuan dari metode ini ialah untuk meningkatkan sifat keterbukaan, toleransi atas perbedaan-perbedaan individu, lebih memperhatikan kebutuhan orang lain, saling menghargai dan mengurangi sikap mau menang sendiri.

e. In Basket Exercise. Pada metode ini peserta diberi permasalahan yang harus dipecahkan dalam batasan-batasan tertentu. Disini peserta dituntut untuk dapat memilih mana masalah yang penting, dan mengambil keputusan atau melakukan tindakan yang tepat dalam waktu relatif singkat.

f. Management Games. Peserta diminta berperan sebagai manager suatu organisasi simulasi. Berdasarkan data yang disediakan, peserta diminta untuk mengambil keputusan.

2. Metode Untuk Pembinaan Technical Skill

a. On The Job Training. Pada metode ini peserta dihadapkan pada lingkungan kerja, lalu mereka diberi instruksi tentang cara-cara bekerja.

b. Vestibule Training. Peserta ditempatkan di dalam ruang yang terpisah dari ruangan pekerjaan yang sesungguhnya, tapi dengan menggunakan alat dan bahan yang sebenarnya.

c. Apperenticeship Training. Biasanya dikenal dengan sistem magang, atau belajar sambil bekerja atau bekerja sambil belajar. Program ini memerlukan waktu yang cukup lama dan pengawasan yang terus menerus.

\section{H. Indikator pendidikan dan pelatihan}

Adapun indikator dari pendidikan dan pelatihan adalah menurut Rae dalam (Sofyandi, Herman, 2013:131) yaitu :

1. Isi pendidikan dan pelatihan, yaitu apakah isi program pendidikan dan pelatihan relevan dan sejalan dengan kebutuhan pendidikan dan pelatihan, dan apakah pendidikan dan pelatihan tersebut up to date.

2. Metode pendidikan dan pelatihan, apakah metode pendidikan dan pelatihan yang diberikan sesuai untuk subjek itu dan apakah metode pendidikan dan pelatihan tersebut sesuai dengan gaya belajar peserta pendidikan dan pelatihan.

3. Sikap dan ketrampilan instruktur, yaitu apakah instruktur mempunyai sikap dan ketrampilan penyampaian yang mendorong orang untuk belajar.

4. Lama waktu pendidikan dan pelatihan, yaitu berapa lama waktu pemberian materi pokok yang harus dipelajari dan seberapa cepat tempo penyampaian materi tersebut.

5. Fasilitas pendidikan dan pelatihan, yaitu apakah tempat penyelenggaraan pendidikan dan pelatihan dapat dikendalikan oleh instruktur, apakah relevan dengan jenis pendidikan dan pelatihan, dan apakah makanannya memuaskan. Selain itu indikator yang dapat mengukur variabel pendidikan dan pelatihan meliputi : (Anwar, 2013:76).

a. Waktu pelaksanaan pendidikan dan pelatihan, yang mencakup: 
- Frekuensi peserta mengikuti pendidikan dan pelatihan.

- Kesesuaian pelaksanaan pendidikan dan pelatihan dengan waktu yang ditetapkan

b. Peserta pendidikan dan pelatihan, yang mencakup:

- Intensitas kehadiran peserta

- Latar belakang pendidikan

c. Metode penyampaian pendidikan dan pelatihan, yang mencakup:

- Mekanisme penyampaian materi pendidikan dan pelatihan oleh instruktur

- Peran/partisipasi aktiv peserta dalam kegiatan pendidikan dan pelatihan

- Komunikasi antara instruktur dan peserta pendidikan dan pelatihan

d. Instruktur, yang mencakup:

Kemampuan/penguasaan struktur terhadap materi pendidikan dan pelatihan

e. Sarana dan prasarana pendidikan dan pelatihan, yang mencakup:

- Kesesuaian antara tempat pelaksanaan dengan jumlah peserta pendidikan dan pelatihan

- Ketersediaan peralatan, perlengkapan dan kebutuhan pendidikan dan pelatihan

f. Materi pendidikan dan pelatihan, yang mencakup:

- Kesesuaian materi pendidikan dan pelatihan dengan tugas dan pekerjaan peserta

- Penerapan/aplikasi materi pendidikan dan pelatihan dalam pelaksanaan tugas

\section{Evaluasi Hasil Pendidikan Dan Pelatihan}

Untuk mengetahui berhasil atau tidaknya suatu program pendidikan dan pelatihan, perlu dilakukan evaluasi setelah program tersebut dilaksanakan. Tujuan dari evaluasi ini adalah untuk mengetahui apakah pendidikan dan pelatihan yang telah dilaksanakan dapat mencapai sasaran yang telah ditetapkan oleh perusahaan. Bila masih terdapat kekurangankekurangan dar program tersebut, maka dapat dilakukan perbaikan-perbaikan sehingga perusahaan dapat meningkatkan program pendidikan dan pelatihan di masa yang akan datang.

Berikut ini pendapat ahli mengenai evaluasi program pendidikan dan pelatihan. Menurut Sikula (2002:64) menyatakan bahwa terdapat beberapa cara mengavaluasi suatu program pendidikan dan pelatihan, yaitu: :

1. Participation Reaction (reaksi partisipasi). Dengan menanyakan langsung kepada peserta tentang apa yang mereka dapat dari pendidikan dan pelatihan tersebut. Evaluasi ini dapat dilaksanakan dengan menggunakan survey opini dengan melakukan wawancara atau dengan menyebarkan kuisioner.

2. Before And After Test Scores (sebelum dan sesudah nilai ujian). Dengan melihat peningkatan nilai test sebelum dengan sesudah pelatihan, sebagai dasar pengukuran keberhasilan program pendidikan dan pelatihan.

3. Before and After Performance Measures (sebelum dan sesudah pengukuran kinerja). Pengukuran dengan menggunakan index prestasi kerja yang sama antara sebelum dan sesudah pelaksanaan program pendidikan dan pelatihan.

4. Experimental And Control Groups (kelompok eksperimen dan kontrol). Merupakan cara evaluasi terbaik, yaitu dengan cara membandingkan job performance antara kelompok yang mengikuti program pendidikan dan pelatihan dengan kelompok yang tidak mengikuti.

Jadi untuk mengevaluasi suatu program pendidikan dan pelatihan yang telah dilaksanakan, maka perlu dilakukan penilaian terhadap prestasi/kemampuan karyawan sebelum dan sesudah karyawan mengikuti pendidikan dan pelatihan. program pendidikan dan pelatihan berhasil atau gagal mencapai sasaran yang diharapkan. 


\section{J. Kinerja Karyawan}

Menurut Mangkunegara (2011:67) mengatakan, "kinerja berasal dari kata Job Performance atau Actual Performance, adalah hasil kerja secara kualitas dan kuantitas yang dicapai seorang pegawai dalam melaksanakan tugasnya sesuai dengan tanggung jawab yang diberikan kepadanya".

Menurut Rivai (2009:548) kinerja merupakan suatu fungsi dari motivasi dan kemampuan. Untuk menyelesaikan tugas atau pekerjaan seseorang sepatutnya memiliki derajat kesediaan dan tingkat kemampuan tertentu. Kesediaan dan keterampilan seseorang tidaklah cukup efektif untuk mengerjakan sesuatu tanpa pemahaman yang jelas tentang apa yang akan dikerjakan dan bagaimana mengerjakannya. Kinerja merupakan prilaku nyata yang ditampilkan setiap orang sebagai prestasi kerja yang dihasilkan oleh karyawan sesuai dengan perannya dalam perusahaan. Kinerja karyawan merupakan suatu hal yang sangat penting dalam upaya perusahaan untuk mencapai tujuannya.

Sedangkan menurut Hasibuan (2009:105) kinerja karyawan adalah suatu hasil yang dicapai oleh seseorang dalam melaksanakan tugas-tugas yang dibebankan kepadanya yang didasarkan atas kecakapan, pengalaman dan kesungguhan serta waktu. Sesuai dengan uraian beberapa ungkapan teori diatas yang telah dikemukakan tersebut dapat disimpulkan bahwa kinerja merupakan hasil-hasil fungsi pekerjaan/kegiatan seseorang atau kelompok dalam suatu organisasi yang dipengaruhi oleh berbagai faktor untuk mencapai tujuan organisasi dalam periode waktu tertentu.

\section{K. Faktor-faktor Yang Mempengaruhi Kinerja}

Menurut Mathis (2006:113) ada tiga faktor utama yang mempengaruhi bagaimana individu melakukan pekerjaannya, tiga faktor utama tersebut yaitu :

1. Kemampuan individual
a. bakat
b. minat
c. faktor kepribadian

2. Tingkat usaha yang dicurahkan
a. motivasi
b. etika kerja
c. kehadiran
d. rancangan tugas

3. Dukungan organisasi
a. Pelatihan dan pengembangan
b. Peralatan dan teknologi
c. Standar kinerja
d. Manajemen dan rekan kerja

\section{Indikator Kinerja}

Indikator kinerja karyawan menurut Mathis dan Jackson (2006:378) yaitu:

1. Kualitas. Kualitas kerja diukur dari persepsi karyawan terhadap kualitas pekerjaan yang dihasilkan serta kesempurnaan tugas terhadap keterampilan dan kemampuan karyawan.

2. Kuantitas. Merupakan jumlah yang dihasilkan dinyatakan dalam istilah seperti jumlah unit, jumlah siklus aktivitas yang diselesaikan.

3. Waktu kerja. Menetapkan waktu kerja yang dianggap paling efisien pada semua level dalam manajemen disuatu perusahaan atau organisasi. Waktu kerja merupakan dasar bagi seorang karyawan dalam menyelesaikan suatu produk atau jasa yang menjadi tanggung jawabnya. 


\section{Volume 18 Nomor 2}

4. Kerja sama dengan rekan kerja. Kerja sama merupakan suatu tuntutan bagi keberhasilan perusahaan dalam mencapai tujuan yang ditetapkan, sebab dengan adanya kerjasama yang baik maka akan memberikan kepercayaan pada berbagai pihak yang berkepentingan baik secara langsung maupun tidak langsung dengan perusahaan.

\section{Proses penilaian Kinerja}

Proses penilaian kinerja menurut Hariandja (2002:199) kinerja harus dikaitkan dengan usaha pencapaian hasil kerja yang diharapkan, maka harus ditentukan tujuan-tujuan setiap pekerjaan kemudian penentuan standar kinerja serta ukurannya, diikuti dengan penentuan metode penilaian pelaksanaan dan evaluasi. Proses tersebut dapat dilihat pada seperti pada gambar berikut:

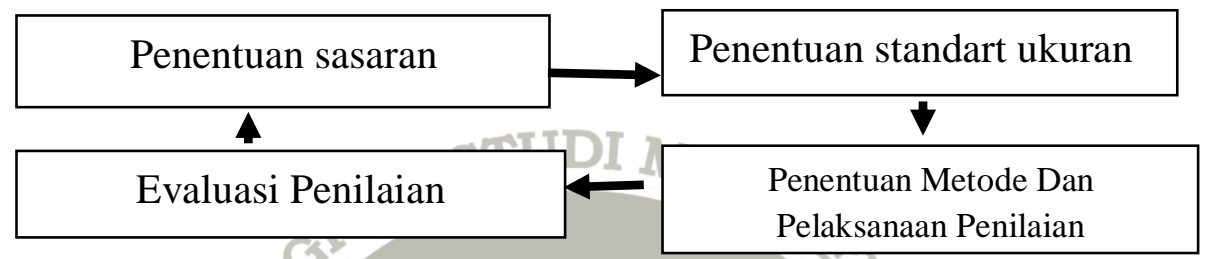

Gambar 1 Proses Penilaian Kinerja

1. Penentuan Sasararan. Penentuan sasaran sebagaimana disebutkan harus spesifik, terukur, menantang, dan didasarkan pada waktu tertentu. Disamping itu perlu pula diperhatikan proses penentuan sasaran tersebut, yaitu diharapkan sasaran tugas individu dirumuskan bersama-sama antara atasan dan bawahan. Setiap sasaran merupakan sasaran yang diturunkan atau yang diterjemahkan dari sasaran yang lebih tinggi. Jadi sasaran unit adalah bagian dari sasaran perusahaan.

2. Penentuan Standar Prestasi Kerja. Pelaksanaan penilaian harus mencerminkan pelaksanaan prestasi kerja yang sesungguhnya atau mengevaluasi perilaku yang mencerminkan keberhasilan pelaksanaan pekerjaan. Untuk itu sistem penilaian prestasi kerja harus :

a. Mempunyai standar. Mempunyai standar berarti mempunyai dimensi-dimensi yang menunjukkan perilaku kerja yang sedang dinilai, yang umumnya diterjemahkan dari sasaran kerja, misalnya hasil kerja berupa barang yang dihasilkan, kuantitas dan kualitas, kehadiran ditempat kerja, kepatuhan terhadap peraturan prosedur dan lainlain.

b. Memiliki ukuran yang dapat dipercaya

Ukuran yang dapat dipercaya dengan pengertian bilamana digunakan oleh orang lain dalam waktu yang berbeda akan menghasilkan kesimpulan yang sama, misalnya ukuran kuantitas yang baik berarti sesuai dengan target, ukuran kualitas yang berarti tidak ditemukan barang yang cacat, ukuran kehadiran yang baik berarti tidak pernah absen kerja tanpa alasan dan lain-lain.

3. Penentuan metode dan pelaksanan penilaian. Metode yang dimaksudkan disini adalah pendekatan atau cara serta perlengkapan yang digunakan seperti formulir dan pelaksananya. Metode-metode perbandingan, tes dan lain-lain.

4. Evaluasi Penilaian. Merupakan pemberian umpan balik kepada kaaryawan mengenai aspek-aspek hasil kerja yang harus diubah dan dipertahankan serta berbagai tindakan yang harus diambil, baik oleh perusahaan maupun karyawan dalam upaya perbaikan kinerja pada masa yang akan datang.

\section{N. Manfaat Penilaian Kinerja}

Pada umumnya orang-orang yang berkecimpung dalam manajemen sumber daya manusia sependapat bahwa penilaian ini merupakan bagian penting dari seluruh proses kekaryaan karyawan yang bersangkutan. Hal ini penting juga bagi perusahaan dimana 
karyawan tersebut bekerja. Bagi karyawan, penilaian tersebut berperan sebagai umpan balik tentang berbagai hal seperti kemampuan, kelebihan, kekurangan, dan potensi yang pada gilirannya bermanfaat untuk menentukan tujuan, jalur, rencana dan pengembangan karir. Dan bagi organisasi atau perusahaan sendiri, hasil penilaian tersebut sangat penting dan peranannya dalam pengambilan keputusan tentang berbagai hal, seperti identifikasi kebutuhan program pendidikan dan pelatihan, rekruitmen, seleksi, program pengenalan, penempatan, promosi, sistem imbalan dan berbagai aspek lain dari proses dari manajemen sumber daya manusia secara efektif.

\section{METODE PENELITIAN}

\section{A. Ruang lingkup Penelitian}

Penelitian ini dilakukan untuk mengetahui perbandingan kinerja karyawan sebelum dan sesudah pemberian pendidikan dan pelatihan kerja. Penelitian ini akan dilakukan pada PT. Asuransi Intra Asia cabang Medan di Jalan H. Adam Malik No. 20 D Medan.

\section{B. Populasi dan Sampel}

Menurut Sugiyono (2010:115) mengatakan bahwa populasi adalah wilayah generalisasi, yang terdiri atas objek atau subjek yang mempunyai kualitas dan karakteristik tertentu yang diterapkan oleh peneliti untuk dipelajari kemudian ditarik kesimpulannya. Populasi pada penelitin ini adalah karyawan bagian agen asuransi PT. Asuransi Intra Asia Cabang Medan, yang berjumlah 35 orang. Penarikan sampel yang digunakan adalah sampling jenuh atau sensus. Menurut Sugiyono (2008:85) sampling jenuh adalah teknik penentuan sampel apabila semua populasi dijadikan sebagai sampel yaitu sebanyak 35 orang karyawan bagian agen asuransi PT. Asuransi Intra Asia Cabang Medan.

\section{Operasional Variabel}

Operasionalisasi Variabel adalah batasan pokok permasalahan yang akan diteliti dan diamati sesuai dengan perumusan masalah. Adapun sebagai operasionalisasi Variabel yaitu:

1. Kinerja karyawan sesudah pemberian pendidikan dan pelatihan kerja (X1), yaitu banyaknya polis asuransi yang terjual sesudah pemberian pendidikan dan pelatihan kerja terhadap karyawan.

2. Kinerja karyawan sebelum pemberian pendidikan dan pelatihan kerja (X2), yaitu Banyaknya polis asuransi yang terjual sebelum pemberian pendidikan dan pelatihan kerja terhadap karyawan.

\section{Teknik Pengumpulan Data}

Pendekatan penelitian yang digunakan dalam penelitian ini adalah pendekatan kuantitatif, yaitu penelitian yang menitik beratkan pada pengujian hipotesis. Sumber data dalam penelitian ini menggunakan data internal, yaitu data yang berasal dari dalam instansi itu sendiri. Sumber data diperoleh dari PT. Asuransi Intra Asia Cabang Medan. Teknik pengambilan data yang digunakan dalam penelitian ini yaitu :

1. Dokumentasi, yaitu data penelitian yang diperoleh secara tidak langsung melalui media perantara (diproleh dan dicatat pihak lain), seperti data laporan pencapaian nilai polis karyawan tahun 2017

2. Wawancara, yaitu proses tanya jawab dalam penelitian yang berlangsung secara lisan dimana dua orang atau lebih bertatap muka mendengarkan secara langsung informasiinformasi atau keterangan-keterangan (Supardi,2006:99).

\section{E. Teknik Analisis Data}

Berdasarkan data yang tersedia sesuai judul penelitian ini, metode analisa sesuai yang digunakan adalah uji beda dua rata-rata sampel berpasangan yang berguna untuk 
mengetahui perbedaan kinerja karyawan sebelum dan sesudah pemberian pendidikan dan pelatihan digunakan uji $\mathrm{z}$ dengan rumus:

$$
\begin{aligned}
& \mathrm{z}=\frac{\bar{D}}{S_{D / \sqrt{n}}} \\
& \bar{D}=\frac{\Sigma D}{n} \\
& \mathrm{SD}=\frac{\sqrt{\Sigma(D-\bar{D})^{2}}}{n-1}
\end{aligned}
$$

dimana:

$\mathrm{z} \quad=\mathrm{z}$ - hitung

$\bar{D} \quad$ = rata-rata kinerja karywan pradiklat dikurangi rata-rata kinerja karyawan pasca diklat

$S_{D}=$ Standar Deviasi

$\mathrm{n} \quad=$ jumlah sampel

$\mathrm{D}=$ selisih kinerja karyawan pasca diklat dengan pradiklat.

Pengujian hipotesis :

Pengujian hipotesa nihil dan alternatif

1. $\mathrm{H}_{0}: \mu_{1}=\mu_{2}$, artinya tidak ada perbedaan yang signifikan anatra kinerja karyawan sebelum dan sesudah pemberian pendidikan dan pelatihan kerja.

$\mathrm{H}_{1}: \mu_{1} \neq \mu_{2}$, artinya ada perbedaan yang signifikan antara kinerja karyawan sebelum dan sesudah pemberian pendidikan dan pelatihan kerja.

2. Jumlah sampel $=$ total karyawa agen asuransi yaitu 35 orang dengan level of signification $=a$ $=5 \%$

3. Daerah kritis dengan taraf nyata sebesar $\alpha=5 \%$ secara dua arah menjadi

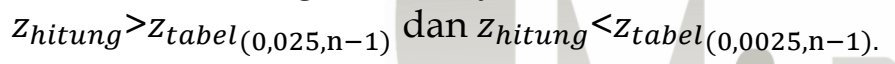

4. Kriteria pengujian:

$\mathrm{H}_{0}$ diterima jika $z_{\text {hitung }} \leq z_{\text {tabel }}(\alpha / 2 ; \mathrm{n}-1)$ atauz $z_{\text {hitung }} \geq z_{\text {tabel }}(\alpha / 2 ; n-1)$

$\mathrm{H}_{0}$ ditolak jika $z_{\text {hitung }}<z_{\text {tabel }}(\alpha / 2 ; \mathrm{n}-1)$ atau $z_{\text {hitung }}>z_{\text {tabel }}(\alpha / 2 ; n-1)$

5. Kesimpulan: dengan membandingkan langkah 3 dan 4 untuk menerima atau menolak hipotesis.

\section{HASIL PENELITIAN DAN PEMBAHASAN}

PT. Asuransi Intra Asia telah digagas pada tahun 1988, yang pada saat itu bernama PT. Asuransi Marannu Mario. Pengalihan kepemilikan terjadi pada tahun 1999 saat PT. Intra Asia Corpora sebagai induk perusahaan membeli mayoritas saham PT. Asuransi Marannu Mario dan melakukan peningkatan modal serta merubah nama perusahaan menjadi PT. Asuransi Intra Asia.

Saat ini modal dasar perusahaan sebesar Rp. 100 Milyar, dengan komposisi modal disetor dari PT. Intra Asia Corpora sebesar Rp. 91.4 Milyar dan koperasi karyawan PT. Jasindo sebesar Rp. 750 juta, dengan jumlah ekuitas perusahaan sebesar Rp. 105.5 Milyar. Dengan eksistensi dan pengalaman lebih dari 27 tahun di industri Asuransi menunjukkan bahwa PT. AIA telah diakui menjadi salah satu perusahaan dibidang asuransi umum yang dapat diandalkan dan telah mendapatkan tempat dan kepercayaan tersendiri di hati para nasabahnya.

Komitmen perusahaan, mengutamakan kepuasan nasabah dengan memberikan kemudahan, kecepatan pelayanan, produk yang inovatif dan tenaga-tenaga profesional . Perusahaan menawarkan berbagai solusi asuransi yang komprehensif, meliputi cakupan layanan bagi nasabah yang lebih luas, mulai dari individu, perusahaan hingga pasar komersial, serta membangun dan membina hubungan jangka panjang dan kemitraan yang erat disegala situasi. Kini perusahaan telah memiliki berbagai produk asuransi di dua puluh (20) kantor cabang dan pemasaran diseluruh indonesia. Perusahaan akan terus tumbuh untuk 
meningkatkan pelayanan dengan lebih responsif dan terdepan kepada nasabahnya, baik nasabah individu, lembaga keuangan, perushaan pembiayaan, sampai broker dan agen.

\section{A. Karakteristik Responden}

Karakteristik responden diukur dari jenis kelamin, umur, pendidikan dan masa kerja yang diperoleh peneliti melalui hasil wawancara dari setiap agen asuransi pada PT. Asuransi Intra Asia Cabang Medan.

Tabel 1. Responden

\begin{tabular}{|c|c|c|}
\hline Uraian & $\begin{array}{l}\text { Jumlah } \\
\text { (Orang) }\end{array}$ & Persen (\%) \\
\hline Jenis Kelamin & & \\
\hline Laki-laki & 18 & $51 \%$ \\
\hline Perempuan & 17 & $49 \%$ \\
\hline Jumlah & 35 & $100 \%$ \\
\hline Umur & 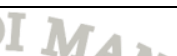 & \\
\hline Kurang dari 25 tahun & 6 & $17 \%$ \\
\hline 26 - 35 tahun & 15 & $42 \%$ \\
\hline $36-45$ tahun & 11 & $31 \%$ \\
\hline $46-55$ tahun & 3 & $10 \%$ \\
\hline Jumlah & 35 & $100 \%$ \\
\hline Pendidikan & & \\
\hline SMA/Sederajat & 13 & $37 \%$ \\
\hline Diploma & 10 & $29 \%$ \\
\hline Sarjana & 12 & $34 \%$ \\
\hline Jumlah & 35 & $100 \%$ \\
\hline Masa kerja & & $\sigma^{\prime}$ \\
\hline 1-5 Tahun & 14 & $40 \%$ \\
\hline 6-10 Tahun 4,5 & 21 & $60 \%$ \\
\hline Jumlah & $\mathrm{N}_{35}$ & $100 \%$ \\
\hline
\end{tabular}

\section{Sumber: Diolah oleh penulis}

\section{B. Pendidikan dan Pelatihan Karyawan pada PT. Asuransi Intra Asia Cabang Medan}

Pendidikan dan pelatihan karyawan agen , secara garis besar terdiri dari dua kelompok, yaitu pelatihan yang dilakukan didalam perusahaan dan pelatihan yang dilakukan diluar perusahaan. Pelatihan didalam perusahaan dilakukan dengan menggunakan instruktur dari dalam perusahaan, sedangkan pelatihan diluar perusahaan dilakukakan dengan praktik langsung pada calon nasabah.

Pelatihan bertujuan untuk meningkatkan kemampuan dan pengetahuannya terhadap pekerjaan yang dilakukannya dalam perusahaan. Khusus untuk karyawan yang baru diterima, pelatihan dilakukan dengan materi human relation skill, kerjasama, inisiatif, pengetahuan, serta tanggung jawab dan kejujuran. Hasil dari pelatihan akan dievaluasi setelah tiga bulan. Evaluasi dilakukan terhadap pencapaian target premi karyawan, dimana hasil evaluasi akan dijadikan dasar untuk melakukan diklat kembali. Karyawan akan mengikuti diklat kembali jika target premi tercapai dibawah $50 \%$.

Selanjutnya untuk karyawan yang sudah lama bekerja pada perusahaan, juga akan dilakukan pelatihan berupa pelatihan lanjutan. Pelatihan ini selain untuk meningkatkan kemampuan karyawan memperoleh target yang ditentukan juga untuk dipromosikan pada jabatan lebih tinggi. Materi pendidikan dan pelatihan meliputi pengetahuan dan ketrampilan, 
inisiatif, pengambilan keputusan, kerjasama, kepemimpinan, motivasi, dedikasi pada perusahaan.

Berdasarkan hasil wawancara dengan koordinator lapangan atau kepala marketing, bahwa pelatihan dilakukan perusahaan bertujuan untuk meningkatkan kinerja karyawan, khususnya dalam pencapaian target premi. Berdasarkan pengalaman selama ini, rata-rata 7085\% dari karyawan yang mengikuti pelatihan dapat mencapai target yang ditentukan dan bahkan melebihi target sehingga targetnya ditingkatkan. Hanya sekitar $15-30 \%$ karyawan yang tidak memenuhi kriteria pencapaian target premi sehingga harus mengikuti pelatihan kembali.

\section{Kinerja Karyawan pada PT. Asuransi Intra Asia Cabang Medan}

Pada setiap perusahaan, pimpinan perusahaan selalu mengharapkan agar para agen dapat bekerja secara efektif sehingga hasil yang diperoleh dapat maksimal. Kinerja menunjukkan tingkat produktivitas seorang karyawan di dalam melaksanakan pekerjaannya. Pengukuran kinerja karyawan, khususnya agen dilakukan berdasarkan target pencapaian jumlah polis yang terjual atau jumlah premi yang masuk. Hal ini juga menjadi pengukuran kinerja perusahaan secara umum, sehingga dengan demikian semua karyawan baik administratif, manajemen dan supervisor beserta agen bawahannya akan selalu bekerja sama untuk mencapai target penerimaan yang telah ditentukan perusahaan. Pencapaian target merupakan salah satu kriteria pengukuran kinerja setiap unit perusahaan, dan menjadi tanggung jawab dari pimpinan pada setiap cabang perusahaan.

Untuk menjamin agar target jumlah premi dapat tercapai, dilakukan pertemuan rutin setiap akhir bulan untuk mengevaluasi hasil kerja yang telah dicapai, khususnya dalam penerimaan premi. Selain merupakan bentuk pengawasan hasil kerja secara rutin, evaluasi hasil kerja bulanan juga mencakup pembahasan tentang upaya-upaya yang harus dilakukan pada bulan berikutnya, sehingga tujuan perusahaan dapat tercapai dan dapat terus ditingkatkan.

Penentuan jumlah target yang harus dicapai merupakan gabungan antara kewajiban yang diberikan oleh kantor pusat kepada cabang dengan kemampuan karyawan. Artinya penentuan target tersebut, perusahaan dipusat memberikan rencana target yang akan dicapai setiap cabang, namun demikian diberikan toleransi jumlah target tersebut sesuai dengan kemampuan karyawan pada setiap cabang. Penentuan rencana target dari kantor pusat didasarkan pada pencapaian target pada tahun-tahun sebelumnya. Berdasarkan ketentuan rencana target tersebut, pimpinan melakukan pertemuan dengan seluruh staf dan marketing dijajarannya untuk membahas target yang harus dicapai setiap bulan, setiap semester dan setiap tahun.

Penentuan periode target bulanan, semester dan tahunan adalah untuk memudahkan melakukan evaluasi, sehingga target dalam jangka waktu yang lebih lama dapat diketahui perkembangannya sejak awal. Artinya pencapaian target bulanan sebenarnya ditentukan dari pencapaian target tahunan dan semesteran sedangkan untuk agen pencapaian target ditentukan oleh marketing masing-masing dari agen asuransi.

Berdasarkan hasil penelitian, diperoleh data tentang kinerja dari setiap agen pada PT. Asuransi Intra Asia Cabang Medan sebagai berikut:

Tabel 2. Kinerja Agen Sebelum dan Sesudah Pemberian Pendidikan dan Pelatihan Kerja

\begin{tabular}{|l|l|c|c|c|c|}
\hline \multirow{2}{*}{ No. } & \multirow{2}{*}{ Nama Agen } & \multicolumn{3}{|c|}{ Pencapaian Jumlah Polis (Rp. Juta) } & \% Selisih \\
\cline { 3 - 5 } & & Pra Diklat & Pasca Diklat & Selisih & \\
\hline 1. & Abel Zekonia & 80 & 90 & 10 & 12,50 \\
\hline 2. & Dicky Reksa & 200 & 310 & 110 & 55 \\
\hline 3. & Sahala Tambun & 360 & 510 & 150 & 41,67 \\
\hline 4. & Desi Afriani & 200 & 212 & 12 & 6,00 \\
\hline
\end{tabular}


Volume 18 Nomor 2

\begin{tabular}{|c|c|c|c|c|c|}
\hline 5. & Johanes Putra Ompusunggu & 120 & 80 & -40 & $-33,33$ \\
\hline 6. & Sion Tarigan & 120 & 100 & -20 & $-16,67$ \\
\hline 7. & Dimas Hutabarat & 60 & 90 & 30 & 50,00 \\
\hline 8. & Arman Sitepu & 60 & 70 & 10 & 16,67 \\
\hline 9. & Zulkipli & 80 & 100 & 20 & 25 \\
\hline 10. & Jeremia Sebastian Sembiring & 120 & 180 & 60 & 50 \\
\hline 11. & Arah Ukurta Ginting & 120 & 120 & 0 & 0 \\
\hline 12. & Dekon Pinem & 120 & 128 & 8 & 6,67 \\
\hline 13. & Sempakata Purba & 120 & 132 & 12 & 10 \\
\hline 14. & Hizkia Pinem & 60 & 50 & -10 & $-16,67$ \\
\hline 15. & Nurita Depari & 200 & 184 & -16 & $-8,00$ \\
\hline 16. & Johana & 60 & 80 & 20 & 33,33 \\
\hline 17. & Lisna Wati Sipayung & 60 & 82 & 22 & 36,67 \\
\hline 18. & Dermawan Situmorang & 80 & 120 & 40 & 50 \\
\hline 19. & Risma Uli Sinaga & $560-1$ & $24>60$ & 0 & 0 \\
\hline 20. & Sri Ulina Ginting & 60 & 96 & 36 & 60 \\
\hline 21. & Ruth Natalia Pinem & 60 & 80 & 20 & 33,33 \\
\hline 22. & Sri Mitha Tarigan & 475 & 605 & 270 & 27,37 \\
\hline 23. & Santa Elsela Tarigan & 340 & 410 & 70 & 20,59 \\
\hline 24. & VeraLina Wati Butar-Butar & 320 & 425 & 105 & 32,81 \\
\hline 25. & Qairul Fahliza & 80 & 110 & 30 & 37,50 \\
\hline 26. & Vicky Ulfa Romiata & 70 & 95 & 25 & 35,71 \\
\hline 27. & Sandyka Bastian Sipayung & 230 & 240 & 10 & 4,34 \\
\hline 28. & Desi Wulandari & 75 & $95 \quad 0$ & 20 & 26,67 \\
\hline 29. & Rika Phadila & 60 & 80 & 20 & 33,33 \\
\hline 30. & Basaria Rajagukguk & 180 & $210 \times 0$ & 30 & 16,67 \\
\hline 31. & Devita Lumbangaol & 350 & 400 & 50 & 14,28 \\
\hline 32. & Rani Novia & 80 & 100 & 20 & 25 \\
\hline 33. & Saiful Haris & 95 & SA 90 & -5 & $-5,26$ \\
\hline 34. & Rudini Silian & 250 & 270 & 20 & 8 \\
\hline \multirow[t]{3}{*}{35.} & Dewi Kumala Sari Ginting & 90 & 100 & 10 & 11,11 \\
\hline & Jumlah & 5.095 & 6.104 & 1.009 & 700,29 \\
\hline & Rata-Rata & 145,57 & 174,4 & 28,83 & 20,01 \\
\hline
\end{tabular}

Sumber: Diolah oleh Penulis

Berdasarkan tabel di atas, rata-rata pencapaian jumlah nilai polis dari setiap agen sesudah melakukan pendidikan dan pelatihan lebih tinggi dibandingkan dengan sebelum menerima pendidikan dan pelatihan. Rata-rata pencapaian nilai polis agen sesudah menerima pendidikan dan pelatihan adalah Rp. $174.400 .000,00$. Sedangkan jumlah pencapaian nilai polis agen sebelum mendapat pendidkan dan pelatihan sebesar Rp.145.570.000,00. Dengan demikian pencapaian nilai polis karyawan sesudah pendidikan dan pelatihan lebih tinggi sebesar Rp. 28.830.000,00 atau 20,01\% dari sebelum mendapat pendidikan dan pelatihan kerja.

\section{Uji Beda Dua Rata-Rata Sampel Berpasangan}

Uji beda dua rata-rata sampel berpasangan bertujuan untuk melihat pengaruh sebelum dan sesudah dilakukan suatu kegiatan tertentu. Dalam penelitian ini untuk melihat perbedaan kinerja karyawan, sebelum dan sesudah melakukan pendidikan dan pelatihan . Untuk menganalisis perbedaan kinerja tersebut, dilakukan dengan uji beda dua rata-rata, yang perhitungannya ditunjukkan pada tabel berikut : 
Volume 18 Nomor 2

Tabel 3. Analisis Perbedaan Kinerja Karyawan Sebelum dan Sesudah Pemberian Pendidikan dan Pelatihan Kerja

\begin{tabular}{|c|c|c|c|c|c|c|}
\hline \multirow[t]{2}{*}{ No } & \multirow[t]{2}{*}{ Nama Agen } & \multicolumn{3}{|c|}{$\begin{array}{l}\text { Pencapaian Jumlah Polis (Rp. } \\
\text { Juta) }\end{array}$} & \multirow[t]{2}{*}{$\bar{D}$} & \multirow[t]{2}{*}{$(D-\bar{D})^{2}$} \\
\hline & & $\begin{array}{l}\text { Pra Diklat } \\
\text { (X1) }\end{array}$ & $\begin{array}{c}\text { Pasca } \\
\text { Diklat } \\
(\mathrm{X} 2)\end{array}$ & $\begin{array}{c}\mathrm{D} \\
(\mathrm{X} 2- \\
\mathrm{X} 1)\end{array}$ & & \\
\hline 1. & Abel Zekonia & 80 & 90 & 10 & 28,82857 & 354,5151 \\
\hline 2. & Dicky Reksa & 200 & 310 & 110 & 28,82857 & 6588,801 \\
\hline 3. & Sahala Tambun & 360 & 510 & 150 & 28,82857 & 14682,52 \\
\hline 4. & Desi Afriani & 200 & 212 & 12 & 28,82857 & 283,2008 \\
\hline 5. & Johanes Putra Ompusunggu & 120 & 80 & -40 & 28,82857 & 4737,372 \\
\hline 6. & Sion Tarigan & 120 & 100 & -20 & 28,82857 & 2384,229 \\
\hline 7. & Dimas Hutabarat & SI60] & 90 & 30 & 28,82857 & 1,372245 \\
\hline 8. & Arman Sitepu & 60 & 70 & 10 & 28,82857 & 354,5151 \\
\hline 9. & Zulkipli & 80 & 100 & 20 & 28,82857 & 77,94367 \\
\hline 10. & Jeremia Sebastian Sembiring & 120 & 180 & 60 & 28,82857 & 971,658 \\
\hline 11. & Arah Ukurta Ginting & 120 & 120 & 20 & 28,82857 & 831,0865 \\
\hline 12. & Dekon Pinem & 120 & 128 & 8 & 28,82857 & 433,8294 \\
\hline 13. & Sempakata Purba & 120 & 132 & 12 & 28,82857 & 283,2008 \\
\hline 14. & Hizkia Pinem & 60 & 50 & -10 & 28,82857 & 1507,658 \\
\hline 15. & Nurita Depari & 200 & 184 & -16 & 28,82857 & 2009,601 \\
\hline 16. & Johana & 60 & 80 & 20 & 28,82857 & 77,94365 \\
\hline 17. & Lisna Wati Sipayung & 60 & 82 & 22 & 28,82857 & 46,62937 \\
\hline 18. & Dermawan Situmorang & 80 & 120 & 40 & 28,82857 & 124,8008 \\
\hline 19. & Risma Uli Sinaga & 60 & 60 & 0 & 28,82857 & 831,0864 \\
\hline 20. & Sri Ulina Ginting & 60 & 96 & 36 & 28,82857 & 51,42941 \\
\hline 21. & Ruth Natalia Pinem & 60 & 80 & 20 & 28,82857 & 77,94365 \\
\hline 22. & Sri Mitha Tarigan & $4751 K$ & 605 & 130 & 28,82857 & 10235,66 \\
\hline 23. & Santa Elsela Tarigan & 340 & 410 & 70 & 28,82857 & 1695,087 \\
\hline 24. & VeraLina Wati Butar-butar & 320 & 425 & 105 & 28,82857 & 5802,087 \\
\hline 25. & Qairul Fahliza & 80 & 110 & 30 & 28,82857 & 1,372248 \\
\hline 26. & Vicky Ulfa Romiata & 70 & 95 & 25 & 28,82857 & 14,65795 \\
\hline 27. & Sandyka Bastian Sipayung & 230 & 240 & 10 & 28,82857 & 354,515 \\
\hline 28. & Desi Wulandari & 75 & 95 & 20 & 28,82857 & 77,94365 \\
\hline 29. & Rika Phadila & 60 & 80 & 20 & 28,82857 & 77,94365 \\
\hline 30. & Basaria Rajagukguk & 180 & 210 & 30 & 28,82857 & 1,372248 \\
\hline 31. & Devita Lumbangaol & 350 & 400 & 50 & 28,82857 & 448,2294 \\
\hline 32. & Rani Novia & 80 & 100 & 20 & 28,82857 & 77,94365 \\
\hline 33. & Saiful Haris & 95 & 90 & -5 & 28,82857 & 1144,372 \\
\hline 34. & Rudini Silian & 250 & 270 & 20 & 28,82857 & 77,94365 \\
\hline 35. & Dewi Kumala Sari Ginting & 90 & 100 & 10 & 28,82857 & 354,515 \\
\hline & Jumlah & 5.095 & 6.104 & 1.009 & & $57.074,97$ \\
\hline
\end{tabular}

\section{Sumber: Diolah oleh Penulis}

Berdasarkan tabel diatas, dapat dilakukan perhitungan uji beda dua rata-rata sebagai berikut:

$\bar{D}=\frac{\Sigma D}{n} \quad \mathrm{SD}=\frac{\sqrt{\Sigma(D-\bar{D})^{2}}}{n-1}$ 
Volume 18 Nomor 2

$$
\begin{array}{ll}
=\frac{1.009}{35} & =\frac{\sqrt{57.074,97}}{34} \\
=28,82857 & \\
& =\frac{238,90}{34} \\
& =7,03
\end{array}
$$

Jadi :

$$
\begin{aligned}
\mathrm{Z} & =\frac{28,83}{7,03 / \sqrt{35}} \\
& =\frac{28,83}{7,03 / 5,92} \\
& =\frac{28,83}{1,19} \\
& =24,23 \\
Z_{0,05 / 2} & =1,9+0,06=1,96
\end{aligned}
$$

Berdasarkan hasil analisis tersebut nilai $z_{\text {hitung }} 24,23>1,96$, yang berarti bahwa terdapat perbedaan yang signifikan antara kinerja karyawan sesudah mendapat pendidikan dan pelatihan dengan sebelum mendapat pendidikan dan pelatihan. Dengan demikian, hipotesis yang diajukan dalam penelitian ini dapat diterima.

Perbedaan yang signifikan antara kinerja karyawan sesudah mendapat pendidikan dan pelatihan dengan sebelum mendapat pendidikan dan pelatihan menunjukkan bahwa program pendidikan dan pelatihan memberikan manfaat yang signifikan bagi kinerja karyawan. Jika perusahaan berkeinginan untuk meningkatkan kinerja karyawannya, hendaknya memberikan pendidikan dan pelatihan kerja secara berkala, khususnya terhadap karyawan-karyawan dengan kinerja yang tidak memenuhi standar begitu juga dengan karyawan yang telah memenuhi standar dalam upaya meningkatkan target polis yang akan dicapai.

\section{E. Pembahasan}

Tujuan pendidikan dan pelatihan adalah untuk meningkatkan kemampuan, pengetahuan, keterampilan, dan dapat bekerja secara efisien. Berdasarkan hasil perhitungan uji beda rata-rata sampel berpasangan, terdapat perbedaan yang signifikan antara kinerja karyawan sesudah dan sebelum mendapatkan pendidikan dan pelatihan. Hal tersebut berarti pendidikan dan pelatihan karyawan memiliki pengaruh yang besar terhadap kinerja karyawan.

Solusi yang dapat dilakukan untuk meningkatkan pendidikan dan pelatihan karyawan yaitu melaksanakan evaluasi pendidikan dan pelatihan bagi karyawan secara rutin minimal setiap 2 kali dalam satu tahun. Evaluasi Pendidikan dan Pelatihan bertujuan mengetahui penerapan hasil pendidikan dan pelatihan oleh peserta penerima pendidikan dan pelatihan pada perusahaan. Selain itu karywan harus sadar akan tanggung jawabnya.

Berdasarkan hasil penelitian ini, terdapat perbedaan yang signifikan antara kinerja karyawan sesudah mendapat pendidikan dan pelatihan dengan sebelum mendapat pendidikan dan pelatihan. Dengan demikian, hipotesis yang diajukan dalam penelitian ini dapat diterima.

Perbedaan yang signifikan antara kinerja karyawan sesudah mendapat pelatihan dengan sebelum mendapat pelatihan menunjukkan bahwa program pendidikan dan pelatihan memberikan manfaat yang signifikan bagi kinerja karyawan. Jika perusahaan berkeinginan untuk meningkatkan kinerja karyawannya, hendaknya memberikan pendidikan dan pelatihan kerja secara berkala, khususnya terhadap karyawan-karyawan dengan kinerja yang tidak memenuhi standar begitu juga dengan karyawan yang telah memenuhi standar dalam upaya meningkatkan target polis yang akan dicapai.

Hasil penelitian ini sejalan dengan hasil penelitian oleh Cut Asmara Nur (2005), mengenai Analisis Perbedaan Kinerja Karyawan PT. Ata Sadira Surabaya Sebelum dan 
Sesudah Outbound Training, menyimpulkan bahwa dari hasil pengujian dengan menggunakan uji beda diketahui bahwa terdapat perbedaan yang signifikan pada kinerja karyawan pada PT. Ata Sadira Surabaya sebelum dan sesudah mengikuti outbound training, hal tersebut dibuktikan dengan besarnya nilai $t_{\text {hitung }}$ yang diperoleh yaitu sebesar $-5,440$ dengan taraf signifikan kurang dari 0,05 yaitu sebesar 0,000. Dengan demikian hipotesis yang diajukan dalam penelitian ini yang menyatakan diduga terdapat perbedaan yang signifikan pada kinerja karyawan PT. Ata Sadira Surabaya sebelum dan sesudah mengikuti outbound training yang dinilai dari faktor-faktor kualitas kerja, kuantitas kerja, keperluan untuk pengawasan dan efisiensi biaya telah terbukti kebenarannya.

Ada perbedaan kinerja keuangan perusahaan sebelum dan sesudah diadakannya Training ESQ yaitu pada PT. Bukit Asam Rasio Perputaran Persediaan. Perusahaan Gas Negara adalah Rasio Lancar, Rasio Cepat, Return On Invesment. Telekomunikasi Indonesia adalah Rasio Cepat, Return On Asset, Rasio Perputaran Persediaan. Indosat adalah Rasio Kelipatan Pembayaran Hutang (TIE). Hal ini berarti, terdapat perbedaan kinerja keuangan sebelum dan sesudah diadakannya Training ESQ, namun peningkatan tersebut tidak signifikan. Hal ini dikarenakan tidak semua karyawan perusahaan mengikuti Training ESQ dan juga rentan waktu dalam pengadaan Training ESQ. Serta kurangnya minat dan kemauan dari para karyawan untuk mengikuti Training ESQ. Karena pelatihan pada karyawan tidak akan berjalan dan menghasilkan suatu hasil yang memuaskan tanpa ada kemauan dari diri mereka sendiri. Kemauan yang dimaksud adalah proses perubahan diri dari kinerja negatif ke positif, dan dari hasil yang tidak memuaskan menjadi lebih memuaskan.

Hal tersebut dikarenakan pendidikan dan pelatihan merupakan salah satu upaya dalam pengembangan sumber daya manusia bagi suatu organisasi, namun peningkatan kinerja karyawan pada masing-masing organisasi mempunyai presentase sendiri, begitu juga pada PT. Asuransi Intra Asia Cabang Medan. Oleh karena itu dapat disimpulkan bahwa dengan adanya pendidikan dan pelatihan bagi karyawan maka karyawan mengalami perubahan- perubahan yang positif bagi karyawan baik pengetahuan, kemampuan dan keterampilan yang semakin meningkat dengan adanya pengembangan sumber daya manusia seperti program pendidikan dan pelatihan kerja ini.

\section{KESIMPULAN}

Pencapaian jumlah nilai polis karyawan sesudah mendapat pendidikan dan pelatihan kerja lebih tinggi dibandingkan dengan sebelum mendapat pendidikan dan pelatihan kerja. Rata-rata jumlah pencapaian nilai polis karyawan sesudah pendidikan dan pelatihan adalah Rp174.400.000,00 sedangkan jumlah pencapaian nilai polis sebelum mendapat pendidikan dan pelatihan adalah Rp145.570.000,00 dengan demikian pencapaian nilai polis karyawan sesudah pendidikan dan pelatihan lebih tinggi sebesar Rp 28.830.000,00 atau 20,01\% dari sebelum mendapat pendidikan dan pelatihan kerja. Berdasarkan hasil analisis tersebut nilai $z_{\text {hitung }} 24,23>1,96$ terdapat perbedaan yang signifikan antara kinerja karyawan sesudah dengan sebelum mendapat pendidikan dan pelatihan kerja pada PT. Asuransi Intra Asia Cabang Medan, kinerja karyawan sesudah pendidikan dan pelatihan lebih tinggi dari sebelum mendapat pendidikan dan pelatihan.

Sesuai dengan hasil penelitian ini, untuk meningkatkan kinerja karyawan, sebaiknya perusahaan melakukan pemberian pendidikan dan pelatihan secara berkala, khususnya terhadap karyawan dengan kinerja yang tidak memenuhi standar dan pemberian pendidikan dan pelatihan terhadap karyawan yang telah memenuhi standar juga perlu dilakukan dalam upaya untuk meningkatkan target polis yang telah ditentukan oleh perusahaan. 


\section{DAFTAR PUSTAKA}

A. A. Anwar Prabu Mangkunegara. 2011. Manajemen Sumber Daya Manusia Perusahaan. Bandung: Rosda.

Bandung: PT. Remaja Rosdakarya.

2013. Manajemen Sumber Daya Manusia Perusahaan.

Ambar Teguh Sulistiyani. 2003. Manajemen Sumber Daya Manusia Edisi Pertama Cetakan Pertama. Yogyakarta: Graha Ilmu.

. 2009, Manajemen Sumber Daya Manusia. Yogyakarta: Graha Ilmu.

Andrew E. Sikula. 2002. Pelatihan dan Pengembangan Tenaga Kerja. Bandung: Erlangga. . 2003. Manajemen Sumber Daya Manusia. Bandung: Erlangga.

Basri, A. F. M., dan Rivai, V. 2005. Performance Appraisal Sistem yang Tepat Untuk Menilai Kinerja Karyawan dan Meningkatkan Daya Saing Perusahaan. Jakarta: PT. Raja Grafindo Persada.

Handoko, T. Hani. 2000. Manajemen Personalia dan Sumber Daya Manusia. Yogyakarta: BPFE UGM.

Hariandja, Marihot Tua Efendi. 2002. Manajemen Sumber Daya Manusia Pengadaan, Pengembangan, Pengkompensasian, dan Peningkatan Produktivitas Pegawai. Jakarta: PT. Gramedia Widiasarana Indonesia.

Hasibuan, S.P. Melayu. 2002. Manajemen Sumber Daya Manusia. Jakarta: PT. Bumi Aksara. . 2006. Manajemen Sumber Daya Manusia, (Edisi Revisi). Jakarta: PT.

Bumi Aksara.

2009. Manajemen Sumber Daya Manusia (Cetakan Ketujuh). Jakarta:

PT. Bumi Aksara.

Herman Sofyandi. 2008. Manajemen Sumber Daya Manusia. Yogyakarta: Graha Ilmu. 2013. Manajemen Sumber Daya Manusia (Cetakan Kedua). Yogyakarta: Graha Ilmu.

Mathis, Robert L. Jackson. 2006. Manajemen Sumber Daya Manusia. Jakarta: Salemba Empat.

Nawawi, Hadari. 2008. Manajemen Sumber Daya Manusia Untuk Bisnis yang Kompetitif. Yogyakarta: Gadjah Mada University Press.

Notoatmodjo, Soekidjo. 2009. Pengembangan Sumber Daya Manusia. Jakarta: PT. Rineka Cipta.

Rivai, Veithzal. 2009. Manajemen Sumber Daya Manusia Untuk Perusahaan dari Teori ke Praktik. Jakarta: Raja Grafindo Persada.

Sedarmayanti. 2011. Sumber Daya Manusia dan Produktivitas Kerja. Bandung: CV. Mandar Maju.

Sugiyono. 2008. Metode Penelitian Bisnis. Bandung: Alfabeta. 2010. Metode Penelitian Kuantitatif Kualitatif dan R \& D. Bandung: Alfabeta.

Sulistiyani, Ambar. T dan Rosidah. 2003. Manajemen Sumber Daya Manusia. Yogyakarta: Graha Ilmu.

Yusuf, Burhanuddin. 2015. Manajemen Sumber Daya Manusia di Lembaga Keuangan Syariah. Jakarta: PT. Raja Grafindo Persada. 